Assurances et gestion des risques

Insurance and Risk Management

\title{
Health Microinsurance: The State of the Art. A Book Review of David M. Dror's Financing Micro Health Insurance-Theory, Methods and Evidence
}

\section{Michel Vaté}

Volume 86, numéro 1-2, juin 2019

URI : https://id.erudit.org/iderudit/1062468ar

DOI : https://doi.org/10.7202/1062468ar

Aller au sommaire du numéro

Éditeur(s)

Faculté des sciences de l'administration, Université Laval

ISSN

1705-7299 (imprimé)

2371-4913 (numérique)

Découvrir la revue

Citer ce document

Vaté, M. (2019). Health Microinsurance: The State of the Art. A Book Review of David M. Dror's Financing Micro Health Insurance-Theory, Methods and Evidence. Assurances et gestion des risques / Insurance and Risk Management, 86(1-2), 117-124. https://doi.org/10.7202/1062468ar

Tous droits réservés (c) Faculté des sciences de l'administration, Université Laval, 2019
Ce document est protégé par la loi sur le droit d'auteur. L'utilisation des services d'Érudit (y compris la reproduction) est assujettie à sa politique d'utilisation que vous pouvez consulter en ligne.

https://apropos.erudit.org/fr/usagers/politique-dutilisation/ 


\section{HEALTH MICROINSURANCE: \\ THE STATE OF THE ART \\ A BOOK REVIEW OF DAVID M. DROR'S \\ FINANCING MICRO HEALTH INSURANCE- \\ THEORY, METHODS AND EVIDENCE}

Michel VATÉ1

"Healthcare for all at affordable prices" this slogan could have been the subtitle of David M. Dror's most recent book Financing Micro Health Insurance-Theory, Methods, and Evidence ${ }^{2}$, as its message paves the course.

\section{WHY THIS BOOK? WHY NOW?}

The author's own words answer the first question: "This book addresses three issues. The first is how to catalyze demand for health insurance and develop insurance literacy among the largely illiterate and innumerate target population, using training programs to build an enabling consensus, allowing locals to create and administer such schemes. The second involves the process of developing simplified methods for risk assessment, which can help to underwrite risks, price the micro health insurance schemes, and ensure proper implementation. The third issue is formulating a compelling business case which would make this health insurance affordable, financially sustainable, and operationally scalable". Such an exercise would be inconceivable without twenty years of immersion in the empirical and academic universe of health microinsurance (HMI). 
Yes, microinsurance is twenty years old. Twenty years are too long to remain bewildered-enthusiastic or skeptical as the case may beabout the innovation. Twenty years are probably too short to claim the complete theoretical and methodological comprehension of a new scientific object that the practitioners have not yet fully validated. However, this book proves that twenty years have been enough to firmly engage in the construction of such knowledge in a way that is socially useful and scientifically rigorous. We explore three essential properties for its viability: internal logic; external compatibility with the surrounding system; general utility. Considering that the HMI is "community-based" and because "like in the case of commercial insurers, MIUs also strive to pay all underwritten claims at all times" (p. 225), no one would want to prolong the HMI experience if it did not deliver welfare gains to the direct stakeholders and meet the minimum requirement of financial viability.

So why publish this book now? Because it is now possible to take stock of state of the art in this domain. The book's five hundred pages are very stimulating for anyone interested in the research of this "young" field of HMI.

\section{FLASHBACK TWENTY YEARS}

We can now talk about inclusive finance without sounding utopian thanks to the success of micro-finance (microcredit, banking, savings). In retrospect, it is easy today to disregard the skepticism, criticism or even hostility that its inventors, Muhammad Yunus, and many others, had to overcome before reaching that point in the 1990s. There remained the much more complicated case of developing insurance. In those days, nobody spoke about microinsurance yet. When people spoke about insurance, they viewed it as a luxury product whose distribution would come with development: the famous $S$ curve of insurance penetration (premiums as \% of the GDP) relative to per capita GDP. As for health risk coverage, nobody imagined that it could be dealt with other than in the form of public social protection systems, but their implementation was challenged by technical and practical hurdles, let alone financial constraints. The concept of microinsurance emerged outside the world of microcredit, and with a focus on health insurance.

It was necessary to "invent" health microinsurance because there was a crying need for a novel solution in the circumstances of that time. For more than 70 years, the Universal Declaration of Human 
Rights proclaimed a right to health and social protection (Article 25). In some countries, people can access one or more of the three methods of health coverage schemes: local groups of mutual aid; insurance companies; and public social security systems. However, in most places, access to any of these systems remains a distant dream as income, education, financial inclusion, or governmental actions are too imperfect.

In 1999, David Dror and Christian Jacquier published an article 3 which proposed "a concept for group-based bealth insurance, or microinsurance." Its aim was precise: "Extending health insurance to the excluded" with well-defined contours of the project: "microinsurance is conceived as an autonomous enterprise, independent of external operators or permanent financial lifelines" and "microinsurance is the enterprise of the community." Thus, a new chapter began.

Ten years later, in 2009, and two years after he established the Micro Insurance Academy in New Delhi, David Dror was bestowed the "Personality of the Year" Award by the Asia Insurance Industry.

Now, twenty years later, the pioneer who remained at the front-line offers a significant milestone in the history of microinsurance with his book Financing Micro Health Insurance.

\section{FINANCING WHAT? AND HOW?}

Financing, insurance, theory: At first sight, the book's title, its methodological rigor and the intensive use of econometric tools give the impression of an extremely technical subject. However, the focus is on real-life questions. The reader meets men and women, communities, living conditions, calculations, hesitations, anxieties, and projects driven by the rejection of fatalism. A whole section of vast "uncovered areas" of development macroeconomics, as well as microeconomics of insurance, is being written.

Dror has demonstrated that the community-based health insurance model can offer a way forward if it is organized as an insurance from the outset. Thus, premiums must reflect both the levels of willingnessto-pay and the confidence level used in calculating the risk of insolvency. This entails a shift from informal reciprocal risk-sharing to rule-based risk transfer, considering the "iron law" of solvency capital requirements. This shift becomes acceptable to the grassroots groups when they understand that such framing of mutual aid is their only 
way to obtain the welfare gains without risking the financial failure of the insurance due to deviant behavior. Hence, insurance education becomes a necessary step in implementing the strict discipline of a more efficient production choice than simply maintaining contingency savings.

\section{A MORE STATISTICAL THAN MACROECONOMIC UNIVERSE}

From start to finish, the text unfolds in a resolutely statistical "atmosphere." Consider for example the model proposed in Chapter 8: "Knowledge of the distribution of health care costs is essential in order to match costs with local levels of willingness-to-pay for health insurance, in order to predict (simulate) the expected performance of the community-based health insurance." From this model, two very interesting lessons can be drawn. First, the very good fit of the data with the lognormal model. This means that the determining factors are numerous and of low individual intensity, that they are independent of each other, and that their effects are multiplicative (rather than additive, when in the distribution is normal). These four characteristics are essential, but the last, most important, demonstrates what statisticians call the Law of Proportionate Effect, which explains both the studied phenomenon (distribution of health care costs) and the predictive uses of the model (calibration of the financial equilibrium). The second lesson emerges from the comparison of a dozen local distributions: overall, they resemble each other except at the left tail, depicting the small values. Modern risk theory teaches that what happens at the tails of a distribution is often more instructive than at its center, as the anomalies at the tails of otherwise well-adjusted distributions are not explained by pure randomness, the explanation must be found in modified behavior that violates the condition of independence. This insight is fundamental for the analysis and implementation.

\section{AN EXTREMELY COMPLEX TOPIC}

The combination of Micro + insurance + health represents an object of rare complexity.

Micro (meaning "community-based" rather than atomistic) is the level of economic analysis, which is the intermediate between an individual (the producer) and the global (national production). It is the domain 
of coalitions, cooperation, partially aggregated measures, meso-analysis, the articulation between statistically distributed quantities. Chapter 20, dealing with the impact, illustrates this point by showing how the overall behavior depends on the (unequal) size of the intermediate groups, their (unequal) financial capacity, their degree of internal cohesion, or their stability.

Insurance is perhaps the most complex operation among all economic transactions. It is simultaneously a risk management tool, a financial product, an inter-temporal arbitration, a form of solidarity, and a service that can only work well with large numbers. The modern insurance industry today benefits from the lessons of centuries-long theoretical and methodological learning, which is enriched today by the bursting of big data. It is time for all this corpus of knowledge to benefit the less fortunate people in the poorest countries as well.

Health, finally, refers to a good that is most difficult to classify in the usual economic nomenclatures, because it is a good without demand, without supply, without market and therefore without price, but it is still a "good" which has a value-yet not the same value for the individual and the community-and which can be very expensive. Moreover, when health is viewed as a component of human capital, as a pillar of what Amartya Sen calls "capability," the definition and value become even more blurred.

In this book, Dror relies on a multitude of sources, which add complexity that also requires a little effort from the reader! As a bonus, we can understand the richness of the HMI concept well beyond onedimensional health insurance. It does much more; by involving the stakeholders from the onset of the process, the protection strategy naturally leads to an empowerment strategy. Moreover, by recognizing that every subscriber is simultaneously a borrower, a producer, a head of household, etc., the insurance provides multiple facets of coverage that cannot be treated independently when the purpose is to reduce the vulnerability to primary risks that hinder the exit from poverty.

\section{A CROSS-CUTtING SUBJECT}

We cannot wait for poor regions to become rich before they implement social security solutions that have worked well elsewhere. However, developing risk coverage at the base of the economic pyramid represents a twofold challenge. First, the internal coherence is the ability of 
the insurance to withstand extreme losses. Chapter 9 deals with how reinsurance might solve this problem in the context where extreme situations could arise either due to extremal events or due to an exceptional accumulation of banal events. Integrating reinsurance from the outset modifies the parameters of the primary insurance to render it more affordable. This is of added relevance for subscribers who, in their specific context, perceive even modest random expenses as catastrophic (see chapters 6 and 10).

The second dimension is the external integration of micro and macro. The rational behavior of the insured (at the microeconomic level) implies that from the outset, the HMI can remain solvent without reliance on exogenous subsidies (Chapter 1, Box 8 and Part 3). The sustainability of this system is contingent on the satisfaction of both conditions. Seen from this perspective, microinsurance differs significantly from micro-credit, but HMI reinforces the sustainability of microfinance in general.

\section{A TREATISE OF APPLIED ECONOMICS}

This book is an authentic treatise on applied economics. Theoretical or methodological issues treated are neither intangible nor speculative, but rational answers to identified problems. The practical recommendations are not recipes that would be dictated by the ease or urgency of the action but are the application of analytical tools to a suitably modeled reality. Developing a theory of the HMI and its financing cannot be limited to providing a "user manual" for the application of a specific technique to a particular object.

A remarkable feature of this book is the very extensive bibliography and literature reviews (Chapters 5 and 11), which are a valuable aid to the researcher or expert who is interested in this topic. It demonstrates that microinsurance interests many people now. Also, we know where to find a more extensive documentary base, or what would be necessary for a deepening of the studied case. According to the specific subject studied, the author proposes methodological resources, from experimental economics (CHAT, real-life experiences ...) or statistical economics (work on the effects of dispersion or concentration indices, relations between quantities distributed in place of aggregates...). 


\section{Micro Health InSURANCE: A NEW TOOL FOR COHESIVE DEVELOPMENT}

Throughout the book, we note Dror's insistence on explaining two complementary issues: On the one hand, that trust, understanding, and therefore insurance education are essential to raising willingness-to-pay for the HMI, and that the basis for estimating the premium should not be zero but the (sometimes high) cost of care that the subscribers pay when uninsured (see chapter 5). On the other hand, that the insurance units must succeed in three imperatives, namely: the simplification and the transparency of the procedures, the rigorous evaluation of both the risks and the welfare gains, and the balance between the claims costs and the income from premiums.

To express this, the author uses the vocabulary of agreement (reflecting the voluntary nature of accepting to enroll): willingness-to-pay, voluntary membership, community-based, consensus, welfare gains, etc. The reader senses that the very fashionable adjective inclusive is not enough. Admittedly, all the tools or methods that are applied to resolve major collective problems such as poverty reduction, food security, or human development must be inclusive. However, because of its binary nature (excluded/included), this adjective does not qualify sufficiently well the role of the community, let alone that of humanity generally. After all, the feudal order was inclusive, as were the communist regimes. Development strategies are aimed at individuals who are, or who should be "active agents of change rather than as passive recipients of dispensed benefits" as A. Sen says. The institutions that drive these strategies need a graduated measurement to guide their choices and evaluate the results of their actions. Simply saying inclusion does not provide information about the quality, intensity, and degree of acceptance of the relationship between each individual and the whole set. The answer that this book proposes is a simple equation: Cohesion $=$ Inclusion + acceptance.

\section{CONCLUSION}

In applied economics, there is a mutual enrichment of research and practical experience. HMI is a case in point: it evolves in advancing human development. Dror's book constitutes a solid basis to raise some new questions, such as how big data can be employed better? What role 
should international organizations (ILO, FAO, WHO, etc.) and the insurance industry play in providing technical assistance at the grassroots level? Or how to articulate microinsurance with a new class of securitized funds (disasters, pandemics, droughts, etc.)? Or, the portability of experiments across locations to succeed in applying the most appropriate models to different contexts. David Dror's book has the merit of motivating researchers-of all ages-to address these questions.

Lyon 14 May 2019

NOTES

1 Professor Emeritus at the University of Lyon, Former Dean of the Faculty of Economics of Lyon, Associate Researcher at the Thomas More Institute (Brussels-Paris)

2 Dror, DM (2018): Financing Micro Health Insurance: Theory, Methods, and Evidence. Dec 2018. Singapore, World Scientific Publishing. World Scientific Series in Health Investment and Financing vol. 2. number 10944, March.ISBN 978-981-3238-47-3, 552 pp. D0l: https://doi.org/10.1142/10944

3 Dror, D.M. and Jacquier, C. (1999). Micro-insurance: Extending health insurance to the excluded, International Social Security Review 52(1): 71-97 